\title{
Erratum to: Neuroprotective Effect of Hesperidin on Aluminium Chloride Induced Alzheimer's Disease in Wistar Rats
}

Arokiasamy Justin Thenmozhi ${ }^{1}$ Tharsius Raja William Raja ${ }^{1}$. Udaiyappan Janakiraman ${ }^{1}$ - Thamilarasan Manivasagam ${ }^{1}$

Published online: 26 August 2015

(c) Springer Science+Business Media New York 2015

Erratum to: Neurochem Res (2015) 40:767-776

DOI 10.1007/s11064-015-1525-1

Unfortunately, a part of the family name of the corresponding author was wrongly tagged as the given name in the original publication. The author name has been corrected in this erratum.

The online version of the original article can be found under doi:10.1007/s11064-015-1525-1.

Arokiasamy Justin Thenmozhi justinthenmozhi@rediffmail.com

1 Department of Biochemistry and Biotechnology, Annamalai University, Annamalai Nagar 608 002, Tamil Nadu, India 